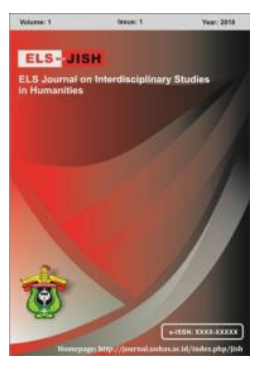

ELS-JISH

ELS Journal on Interdisciplinary Studies on Humanities

Volume 3 Issue 4, 2020

ISSN (print) : 2621-0843

ISSN (online) : 2621-0835

Homepage : http://journal.unhas.ac.id/index.php/jish

\title{
The Implementation of POE (Predict, Observe, Explain) Learning Model to Improve Students' Achievement at Class XI Students of SMA Negeri 10 Makassar
}

\author{
Sukmawati ${ }^{1}$, Bellona Mardhatillah Sabillah² \\ 1'sukmar.dilla@gmail.com
}

\begin{abstract}
This study aimed to determine the implementation of POE (predict, observe, explain) learning model to improve students' achievement at class XI students of SMA Negeri 10 Makassar. This type of research was classroom action research consisting of two cycles. Each cycle of classroom action research was carried out in four (4) stages, namely: planning, implementing, observing, and reflecting. The subjects in this study were 35 class XI students in SMA Negeri 10 Makassar. The result of research indicated that there were 6 students (68.85\%) in cycle I and 33 students (94.28\%) in cycle II that achieved minimum completeness criteria. This research can be concluded that POE learning model can develop students ideas by relating experiences or stories that have been obtained previously. Besides, students' creativity in using diction is very good when presenting the prediction results using the POE method. Thus it is necessary to develop a learning model in the teaching and learning process so that students know very well the meaning of the assessment process of various learning activities.
\end{abstract}

Keywords: POE (Predict,Observe,Explain), Learning Model,Achievement.

How to cite: Sukmawati, \& Sabillah, B. M. (2020). The Implementation of POE (Predict, Observe, Explain) Learning Model to Improve Students' Achievement at Class XI Students of SMA Negeri 10 Makassar. ELS Journal on Interdisciplinary Studies in Humanities, 3(4), 552559. DOI: https://doi.org/10.34050/elsjish.v3i4.11891

\section{Introduction}

Education is the pioner for the development of the nation's civilization, especially Indonesia, to cultivate Human Resources through the learning process consciously. In the process of constructing such as knowledge, students are required to be able to compare the prior knowledge with the new knowledge that they have acquired (Sujarwo and Akhiruddin, 2019). The result can be obtained by the learning process that commonly called teaching result or learning objective. Nevertheless, the learning process must be carried out consciously deliberately, well-planned and organized to obtain optimal results. The learning process is a reciprocal relationship between teachers and students. However, there are still many teachers who are centered in the learning process (teacher centered). In contrast, in language learning it is

\footnotetext{
${ }^{1,2}$ Megarezky University, Makassar, Indonesia
} 
important to increase the knowledge students' skills, able to do scientific work which it is accompanied by an attitude good at interacting (Junaidi, Hamuddin, Simangunsong, Rahman, and Derin, 2020). Many efforts can be made to improve English learning. One of which is by changing teacher-centered learning to student-centered through a learning process. It is hoped that students will be able to find their own building of knowledge and have the process skills to investigate phenomena that occurs in their natural surroundings. Students are expected to be able to understand English skills an integrated manner so that they can develop them in everyday life. It is expected learning like this, but the reality it is still far from being expected because there are still many learning processes that are not following students' nature so that students are often not actively involved in the learning process.

Based on the results of observations, the student's average score was still low. This made students' achievement under Minimum Completeness Criteria (KKM) standard of 75 . Therefore, many students did remedial to achieve KKM based on school standard. It is due to the teacher do not have a varied learning model. One part of learning is the POE (Predict, Observe, Explain) learning model, which is most widely known to help students understand and remind the material they read.

The Predict-Observe-Explain (POE) learning model is a learning model that explores students' prior knowledge and provides opportunities for each student to play role actively in the learning process. The POE learning model directly engages students in the learning process by investigating and obtaining the knowledge gained more meaningful (Suryamiati, Kahar, \& Setiadi, 2019). POE learning can improve the reading comprehension skills of fourth-grade elementary school students (Fathonah, 2017). Besides, POE learning has a significant effect on student learning motivation and competency attainment in improving learning outcomes.(Atriyanti, Y; Hadisaputro, 2015; Restami, Suma, \& Pujani, 2013;Wulandari, Prihandono, \& Maryani, 2018).

The POE learning model can be used by teachers to develop the learning activities and as early learning strategies that are appropriate for students (Rosdianto, Murdani, and Hendra, 2017).Besides, POE learning model can improve on students' science process skills and student learning outcomes (Hsiao, H. S., Chen, J. C., Hong, J. C., Chen, P. H., Lu, C. C., \& Chen, 2017;Rini, A. P., Suryani, N., \& Fadhilah, 2018;Yulianti, S. H., Juanengsih, N., \& Mardiati, 2018). This is line to learning by using efficient POE technique can create a good atmosphere of discussions about the concept of science, because POE learning model includes students in predicting an occurrence, observation through demonstration, and lastly describing the results of their previous demonstrations and forecasts. ( Ayvaci, 2013;Sari, A. T. W. \& Alarifin, 2016). Student is required to make predictions and observe themselves from existing problems to reduce misconception in understanding materials through POE learning model (Fatwadi, Gummah, \& Prasetya, 2019)

Based on the description above, POE (Prediction, Observation, and Explanation) learning models is expected to improve students' achievement in learning reading. The purpose of this study was to determine the implementation of POE (Prediction, Observation, and Explanation) learning 
model to improve students' achievement at class XI students of SMA Negeri 10 Makassar.

\section{Method}

This research was a Classroom Action Research (CAR). According to (Aqib, 2009;Fatwadi et al., 2019) Classroom action research (CAR) is research conducted systematically that describe various actions taken by the teacher in the classroom. This type of research divided into two cycles with four stages, namely: planning, acting, observing, and reflecting.

This research was carried out at SMA Negeri 10 Makassar from April to November 2020. The subjects of this study were class XI students at SMA Negeri 10 Makassar in 2020 with 35 students, including 16 male students and 19 female students. Instruments of research were test and observation.

Each cycle was conducted during four meetings in which the last meeting was carried out a test to measure students' achievement in learning reading into English through POE learning model. The researchers gave different material in each cycle in which the students discussed with the group to predict, observe and explain based on their own words. Data were obtained by the test of the cycle I and cycle II using multiple choice. Besides, the observation took place when each activity was conducted by zoom during pandemic covid-19. Data were analyzed to determine the mean score of cycle I and cycle II and students who can achieve minimum completeness criteria.

\section{Findings and Discussion}

Before collecting data, the researchers prepared several activities which were the stages of classroom action research. This stage consisted of four, namely planning, implementing, observing and reflecting. Researchers collected data at SMA Negeri 10 Makassar using observation sheets and test sheets. Researchers provided an evaluation at the end of each cycle.

\subsection{Planning}

In this stage, the researchers prepared several activities as follows:

a. Prepared material in the form of reading

b. Made a lesson plan (RPP)

c. Made an observation sheet to see the students' participation during the action.

d. Made a test to measure students' reading achievement

e. In the last meeting, students were evaluated to measure the extent to which the implementation of POE learning model on students' achevement.

\subsection{Acting and Observing}

The researchers shared the zoom link to WAG of students and gave greetings to them. The students were given materials using predict, observe and explain (POE) learning model.

a. Predict 
The teacher displayed different reading in each meeting. Then students were asked to predict from the title, main idea and topic. One by one gave comments. Also, the teacher asked for students to make a group and predict the title of a short story. Students were asked for reading the last few sentences of the paragraph, whether it was a conclusion or a message. Moreover, Students did a speed reading at the first sentence at the beginning of the paragraph to find out the point of story

\section{b. Observe}

In this phase, students looked for main ideas, words that were difficult to interpret and then made sentences. Students related to the content of the story with students' experience. Besides, the students discussed what is the passage about; determined name, number, date, words that were repeated; determined new vocabulary and part of speech type.

\section{c. Explain}

Students read the important points that they have made, and other groups gave their comments on the results of group discussions. Students explained by relating this information to what students already have known.

At the fourth meeting, the researcher evaluated to see the extent of the students' achievement with the implementation of the POE learning model. The teacher gave 10 numbers of essays and multiple choice questions in 90 minutes. After that, students submitted their test in the WAG.

\subsection{Reflecting}

After conducting POE learning model in cycle I, the researchers discussed the implementation of the POE learning model. They concluded things that were still lacking and needed improvements in cycle II as follows:

a. There were still many participants who did not understand the main idea

b. There were even some students who were still passive and rely on other groups

c. There were still students who did not understand what was meant by theme.

d. Students' achievement reached the success indicator above 75 , and there were only 16 students who completed and earned the indicator $45.71 \%$

By the result of reflection, the researchers decided to continue cycle II using the same phases as cycle I.

The researchers and the observer discussed the implementation of the POE learning model in cycle II as follows :

a. Almost all students can determine the main idea

b. Some students seemed to be actively discussed and not rely on other groups

c. Students' achievement had achieved success indicators above $75 \%$ as many as 33 students or $94.28 \%$ 
When learning took place, one researcher acted as an observer to monitor whether the implementation of the learning model can be carried out in the classroom. Teacher and students' activity can be seen in the following tables.

Table 1. Teacher's Activity Using POE Learning Model

\begin{tabular}{|c|c|c|c|c|c|c|}
\hline Items & $\begin{array}{l}\text { Meeting I } \\
\text { Cycle I }\end{array}$ & $\begin{array}{l}\text { Meeting II } \\
\text { Cycle I }\end{array}$ & $\begin{array}{l}\text { Meeting III } \\
\text { Cycle I }\end{array}$ & $\begin{array}{l}\text { Meeting I } \\
\text { Cycle II }\end{array}$ & $\begin{array}{l}\text { Meeting } \\
\text { Cycle II }\end{array}$ & $\begin{array}{l}\text { II Meeting III } \\
\text { Cycle II }\end{array}$ \\
\hline 1 & 2 & 5 & 2 & 4 & 4 & 4 \\
\hline 2 & 4 & 5 & 5 & 5 & 5 & 4 \\
\hline 3 & 3 & 3 & 4 & 4 & 4 & 5 \\
\hline 4 & 3 & 3 & 5 & 5 & 5 & 5 \\
\hline 5 & 4 & 3 & 5 & 4 & 5 & 5 \\
\hline 6 & 2 & 5 & 4 & 5 & 4 & 4 \\
\hline 7 & 4 & 3 & 5 & 5 & 4 & 4 \\
\hline 8 & 2 & 3 & 5 & 2 & 5 & 5 \\
\hline 9 & 5 & 4 & 5 & 2 & 5 & 5 \\
\hline 10 & 5 & 3 & 2 & 5 & 3 & 5 \\
\hline Total & 33 & 35 & 39 & $\begin{array}{l}4 \\
1\end{array}$ & $\begin{array}{l}4 \\
4\end{array}$ & $\begin{array}{l}4 \\
6\end{array}$ \\
\hline $\begin{array}{l}\text { Mean } \\
\text { Score }\end{array}$ & 3,3 & 3,5 & 3,9 & 4,1 & 4,4 & 4,6 \\
\hline $\begin{array}{l}\text { Total } \\
\text { Mean } \\
\text { Score }\end{array}$ & 3,56 & & & 4,36 & & \\
\hline
\end{tabular}

Based on table 1, it was found that the mean score of teacher's activity during the three meetings was 3.56 categorized as fair implemented in cycle $\mathrm{I}$. Teacher's activity in cycle II for three meetings was 4.3 which was categorized as good. This illustrated that the teacher had been able to apply the POE learning model.

Table 2. Students' Activity Using POE Learning Model

\begin{tabular}{ccccccc}
\hline Items & $\begin{array}{c}\text { Meeting I Meeting IIMeeting III Meeting I } \\
\text { Cycle I }\end{array}$ & $\begin{array}{c}\text { Meeting II I } \\
\text { Cycle I }\end{array}$ & $\begin{array}{c}\text { Meeting III } \\
\text { Cycle II }\end{array}$ & $\begin{array}{c}\text { Cycle II } \\
\text { Cycle II }\end{array}$ \\
\hline 1 & 3 & 2 & 4 & 4 & 5 & 4 \\
\hline 2 & 5 & 4 & 3 & 4 & 5 & 4 \\
\hline 3 & 3 & 2 & 3 & 4 & 5 & 5 \\
\hline 4 & 2 & 3 & 3 & 5 & 4 & 4 \\
\hline 5 & 3 & 4 & 5 & 4 & 5 & 4 \\
\hline 6 & 2 & 2 & 4 & 5 & 4 & 5 \\
\hline 7 & 3 & 4 & 4 & 5 & 4 & 4 \\
\hline 8 & 3 & 3 & 3 & 4 & 4 & 5 \\
\hline 9 & 5 & 5 & 4 & 2 & 5 & 5 \\
\hline 10 & 3 & 5 & 2 & 5 & 2 & 5 \\
\hline Total & 32 & 34 & 35 & 42 & 43 & 45 \\
\hline Mean & 3,2 & 3,4 & 3,5 & 4,2 & 4,3 & 4,5 \\
Score & & & & & & \\
\hline
\end{tabular}




$\begin{array}{lll}\text { Total } & 3,36 & 4,33\end{array}$

Mean

Score

Based on table 2, it was obtained that the mean score of student activity during the three meetings was 3.36 categorized as good in cycle I. Students' activities in cycle II for three meetings were 4.33 which was categorized as excellen. This illustrates that the implementation of the POE learning model can improve students' activity in learning reading.

Table 3. Criteria of Completeness Classically

\begin{tabular}{lcccc}
\hline Criteria & \multicolumn{2}{c}{ Cycle I } & \multicolumn{2}{c}{ Cycle II } \\
\cline { 2 - 5 } & Frequency & Percentage & Frequency & Percentage \\
\hline Completeness & 16 & $45,71 \%$ & 33 & $94,28 \%$ \\
\hline Incompleteness & 19 & $54,28 \%$ & 2 & $5,71 \%$
\end{tabular}

As described in table 3, it was obtained 16 (45.71\%) students who achieved mastery learning and 19 (54.28\%), students who did not achieve mastery learning as in curriculum for English subjects according to the minimum mastry criteria (KKM), namely 75 in cycle I. Whereas in cycle II, it was found 33 $(94.28 \%)$ students who achieved mastery learning whose score was above KKM and $2(5.71 \%)$ students had not achieved mastery learning above 75.

From the analysis of cycle I to cycle II, there was an improvement of POE learning model on students' achievement. In cycle I was found Students' achievement reached the success indicator above 75, there were only 16 students who completed and got the indicator $45.71 \%$. Those were due to students challenging to predict about the main idea, did not how to organize their thoughts to explain in their own words. Nevertheless, there was an improvement in cycle II. Students' achievement had achieved success indicators above $75 \%$ as many as 33 students or $94.28 \%$. Some factors were found. Namely, students can determine the main idea, theme, retell the short story based on their prediction. Therefore, POE learning model can improve students' achievement in learning reading at class XI students of SMA Negeri 10 Makassar. This was supported by (Fatwadi et al., 2019) that the implementation of the POE learning model has a positive impact on students' grade of VIII SMP Negeri 4 Batukliang Utara. Besides, POE learning model can encourage students to develop their prior knowledge, be more active and creative in the learning process (Farida, Waluyo, \& Fikri, 2018;Setyadi, Sudiarta, \& Mertasari, 2019)

\section{Conclusion}

By the result of research, it was found that most students' achievement obtained learning mastery above a score of 75 . This was due to almost all students can determine the main idea; some students seemed to be actively discussed and not rely on other groups. Besides, the students can predict, observe and explain the short story based on their result of the discussion. This 
research is expected can be a further reference for the next researchers. Therefore, the teachers can use various learning model to make the learning process more fun and more enjoyable. Besides, students are more confident and not bored to learn reading in English.

\section{Acknowledgments}

The researchers say many thanks to Director of Research and Community Service of Ministry of Research Higher Education Technology (DRPM KEMENRISTEKDIKTI) for funding us to conduct this research until at the end of the research. Also headmaster, all teachers and staff of SMA Negeri 10 Makassar who gave us the opportunity in conducting this research, then we appreciate LPPM and our institution Universitas Megarezky.

\section{References}

Aqib, Z. (2009). Penelitian Tindakan Kelas. Bandung: Yrama Widya.

Atriyanti, Y; Hadisaputro, S. (2015). Chemistry in Education. School Science and Mathematics, 2(3), 133-139. https://doi.org/10.1111/j.19498594.1902.tb00418.x

Ayvaci, H. S. (2013). Investigating The Effectiveness of Predict-ObserveExplain Strategy on Teaching Photo Electricity Topic. Journal of Baltic Science Education, 548-564.

Farida, D., Waluyo, J., \& Fikri, K. (2018). The Effect of POE Learning Models (Prediction, Observation, and Explanation) with Probing-Prompting Techniques on The Student's Cognitive Learning Outcomes of SMA Muhammadiyah 3 Jember. Pancaran Pendidikan, 7(3), 51-56. https://doi.org/10.25037/pancaran.v7i3.199

Fathonah, F. S. (2017). Penerapan Model Poe (Predict-Observe-Explain) Untuk Meningkatkan Keterampilan Membaca Pemahaman Siswa Kelas Iv Sekolah Dasar. Jurnal Pendidikan Guru Sekolah Dasar, 1(1), 171-178. https://doi.org/10.17509/jpgsd.v1i1.9070

Fatwadi, A., Gummah, S., \& Prasetya, D. S. B. (2019). Implementation of POE Learning Model with Worksheets Assistance to Improve Students' Activities and Learning Outcomes. Lensa: Jurnal Kependidikan Fisika, 7(1), 10. https://doi.org/10.33394/j-lkf.v7i1.1907

Hsiao, H. S., Chen, J. C., Hong, J. C., Chen, P. H., Lu, C. C., \& Chen, S. Y. (2017). A five-stage prediction- observation-explanation inquiry-based learning model to improve students' learning performance in science courses. Eurasia Journal of Mathematics, Science and Technology Education, $13(7)$, 3393-3416. https://doi.org/https://doi.org/10.12973/eurasia.2017.00735a

Junaidi, J., Hamuddin, B., Simangunsong, W., Rahman, F., \& Derin, T. (2020). ICT usage in teaching English in Pekanbaru: Exploring junior high school teachers' problems. International Journal of Advanced Science and Technology, 29(3), 5052-5063. 
Restami, M. P., Suma, K., \& Pujani, M. (2013). Pengaruh Model Pembelajaran Poe ( Predict-Observe- Explaint) Terhadap Pemahaman Konsep Fisika Dan Sikap Program Studi Pendidikan Sains, Program Pasca Sarjana. EJournal Program Pascasarjana Universitas Pendidikan Ganesha, 3, 1-11.

Rini, A. P., Suryani, N., \& Fadhilah, S. S. (2018). Development of the Predict Observe Explain (POE)-based Thematic Teaching Materials. International Journal of Educational Research Review, 4(1), 1-7. Retrieved from https: //doi.org/10.24331/ijere.458067\%0A

Rosdianto, H., Murdani, E., \& Hendra. (2017). Implementasi Model Pembelajaran POE (Predict Observe Explain) untuk Meningkatkan Pemahaman Konsep Siswa pada Materi Hukum Newton. Jurnal Pendidikan Fisika, 6(1), 55-59.

Sari, A. T. W. \& Alarifin, D. H. (2016). Pengembangan modul berbasis POE (Predict, Observe, Explain) Materi Usaha dan Energi Ditinjau Dari Kemampuan Kognitif. Jurnal Pendidikan Fisika, 4(2), 124-136.

Setyadi, I. M. A., Sudiarta, I. G. P., \& Mertasari, N. M. S. (2019). The effect of predict-observe-explain ( $P O E$ ) learning model using open- ended problem ( OEP ) towards students ' mathematical problem solving skill. Jurnal Pendidikan Dan Pengajaran, 52(3), 133-144.

Sujarwo, et al. (2019). The Application of Problem Solving Reasoning (PSR) in Improving Students' Metacognitive at the Twelfth Grade Students of SMAN 19 Makassar. nternational Journal for Educational and Vocational Studies Vol. 1, No. 2, June 2019, pp. 138-141 Available online at http://ojs.unimal.ac.id/index.php/ijevs.DOl:https://doi.org/10.29103/ijevs.v1i 2.1525

Suryamiati, W., Kahar, A. P., \& Setiadi, A. E. (2019). Improving higher-order thingking skill through POE (Predict, Observe, Explain) and guided discovery learning models. Jurnal Pendidikan Biologi Indonesia, 5(2), 245-252. https://doi.org/10.22219/jpbi.v5i2.8266

Wulandari, T. A., Prihandono, T., \& Maryani. (2018). Analisis Miskonsepsi Siswa pada Materi Suhu dan Kalor di Kelas XI SMA Jember. Inovasi Pendidikan Fisika, 3(1), 434-439. Retrieved from http://ejournal.radenintan.ac.id/index.php/IJSME/article/view/2470.

Yulianti, S. H., Juanengsih, N., \& Mardiati, Y. (2018). POE learning model: The effect on student process on the coordination system concept. JPPS (Jurnal Penelitian Pendidikan Sains ), 8(7). Retrieved from https://journal.unesa.ac.id/index.php/jpps/article/view/3858/2188 